\title{
GENETIC IMPROVEMENT OF SOME PRODUCTIVE TRAITS IN ZARAIBI GOATS
}

\author{
[14] \\ Rasha M. Ahmed ${ }^{1 *}$, Mona A. Osman ${ }^{1}$, Manal Elsayed ${ }^{2}$ and Hussein Mansour ${ }^{2}$ \\ 1- Sheep and Goats Research Dept., Animal Production Res. Inst., Agric. Res. Center, Giza, \\ Egypt \\ 2- Animal Production Dept., Fac. of Agric., Ain Shams Univ., P.O. Box 68, Hadayek Shoubra \\ 11241, Cairo, Egypt
}

*Corresponding author: rasha m39@yahoo.com

Received 5 January, 2020

Accepted 30 January, 2020

\section{ABSTRACT}

The objective of this study was to evaluate the genetic improvement in Zaraibi goats herd raised on El-serw research station located in the north eastern part of Nile Delta, Egypt. The station belongs to Animal Production Research Institute (APRI). Some body weights at different ages were included in genetic and environmental trends. These weights were 4-month weight $(4 \mathrm{M}), 6$-month weight $(6 \mathrm{M})$, and 12-month weight (12M). Data and pedigree information were collected from 1988 until 2018. The least square means of body weights at $4 \mathrm{M}, 6 \mathrm{M}$ and $12 \mathrm{M}$ were $12.14 \pm 0.02,15.49 \pm 0.02$ and $24.08 \pm 0.04$ $\mathrm{kg}$, respectively. Year of birth, season, gender of kid, parity of dam and type of birth significantly $(P<0.01)$ affect growth traits. Genetic parameters were estimated using a multi-trait animal model program (MTDFREML). The same previous fixed effects were included in this analysis regarding the animal as random effects. The heritability of the studied body weights tend to increase as age increases. That is inversely matched with the environmental proportion of total variance which was found to be $0.72,0.66$ and 0.62 for M4, M6 and M12, respectively. The heritability value was estimated as 0.28 for $4 \mathrm{M}$.

Genetic trends were obtained as the regression of the predicted breeding values on years of birth and Environmental trends were obtained as the regression of year constants on years of birth.

The annual genetic change trends were positive and significant for $4 \mathrm{M}, 6 \mathrm{M}$ and $12 \mathrm{M}(0.091,0.121$ and $0.158 \mathrm{~kg} /$ year, respectively) and the annual phenotypic change trends were $(0.020,0.045$, $0.117 \mathrm{~kg} /$ year, respectively). Genetic trends for M12 trait were higher than those for other traits in this study. Genetic and environment correlations between 4 month body weight and other growth traits were positive. Negative environmental trends indicates poor management system for the flock during studied period. Weight at 12 months of age has the highest heritability in studied body weights and suggested to be selection criteria to improve yearling weight for Zaraibi goat.

Keywords: Genetic trend, Growth, Zaraibi, Selection

\section{INTRODUCTION}

Genetic improvement programmers have focused on increasing various economically important traits for higher productivity. Usually in developed countries, goats are considered, as specialty or exotic livestock, whereas in the developing countries, especially those in south-East Asia and Africa goats constitute the major source of meat production (Dhanda et al 2003). Goats are an important source of meat in Egypt and contribute about $5 \%$ of all the red meat production (Galal et al 2005). Zaraibi goat considered the main breed dominates under the harsh conditions and food shortage prevailed in the north western coast of Egypt. Genetic trends in production traits are important in that they allow for the evaluation of the efficacy of selection and management schemes. Many studies have examined genetic trend using regression of estimated breeding values on time (Powell et al 1977; Lee et al 1985). Thus, the present study aimed to evaluate the breeding plan and determine the phenotypic trends, and divide it into its genetic and environmental components. 


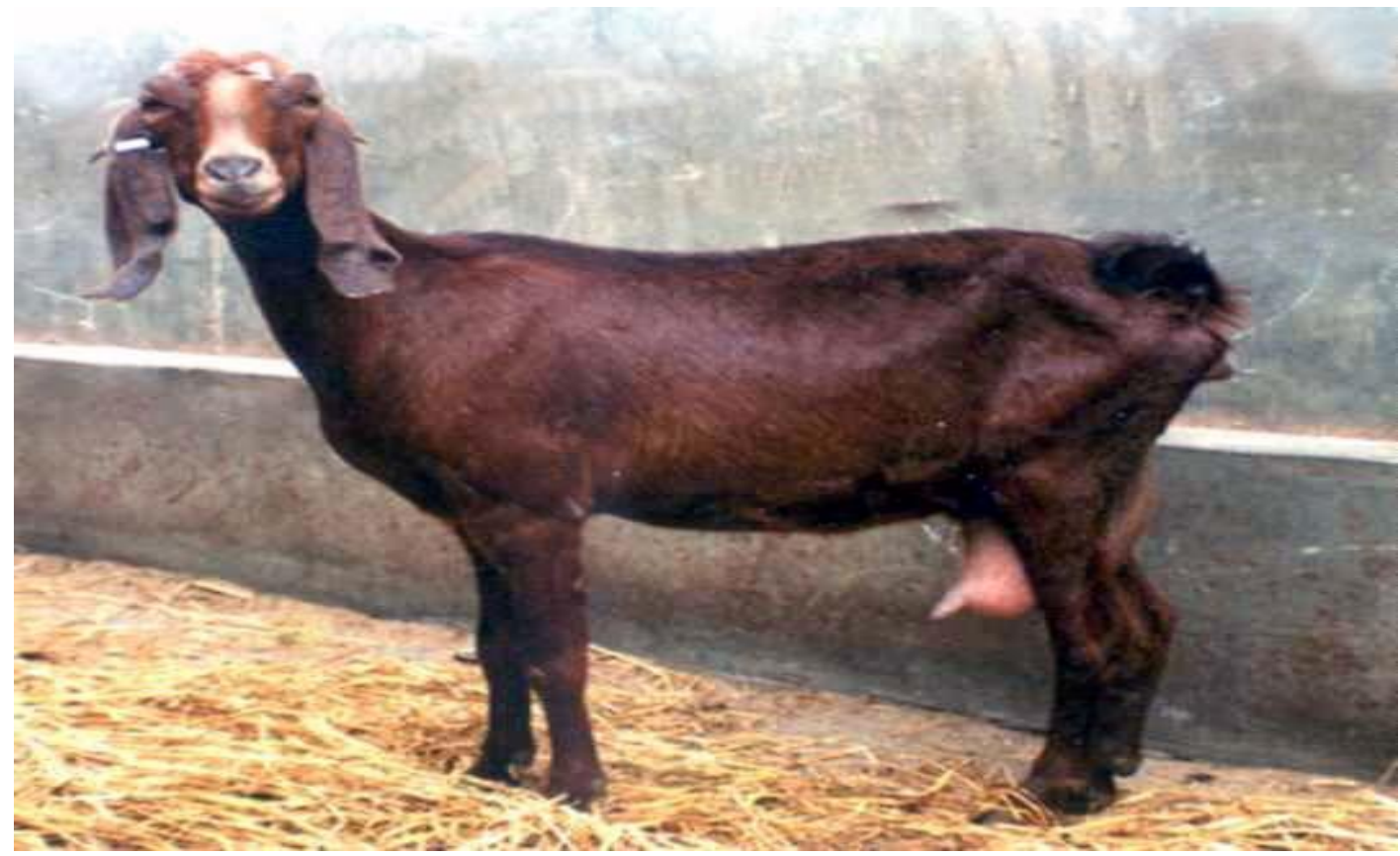

Zaraibi doe (Galal et al 2005)

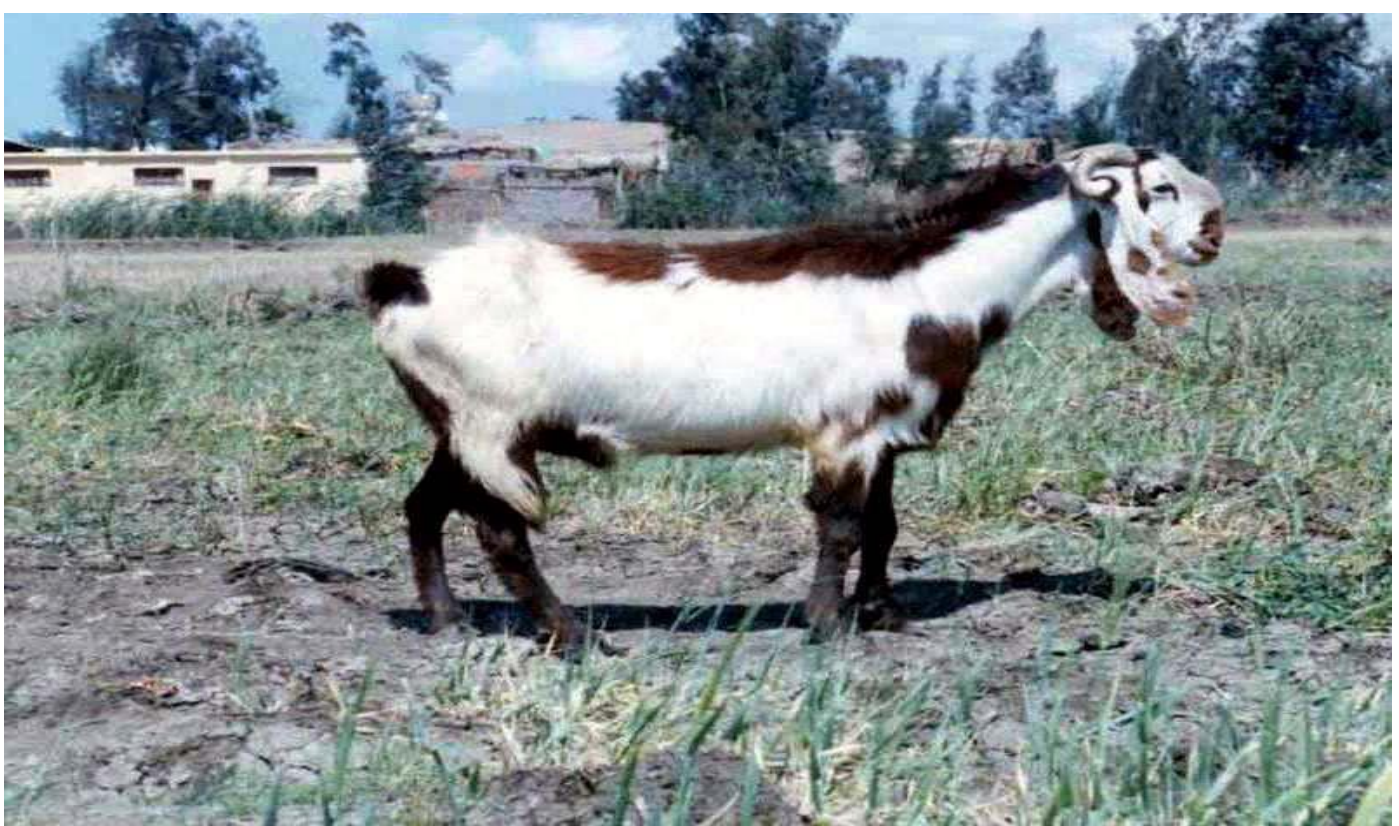

Zaraibi buck (Galal et al 2005) 


\section{MATERIALS AND METHODS}

\section{Data and herd management}

This study was carried out on Zaraibi goats herd kept in El-serw experimental station located in the north eastern part of Nile Delta, Egypt. The station belongs to Animal production Research Institute (APRI), Agriculture Research Center, Ministry of Agriculture.

Data were collected from 1988 to 2018 on 13062 Zaraibi kids progeny of 253 sires and 1447 dams. Measurements were taken on body weight at four month (4M), six month (6M) and twelve month (12M) of age. Kids Weighted within 24 hours after kidding and weighted monthly till 18 months of age. Kids were housed in semi-open and fed on Egyptian clover (Trifolum alexandrinum) from December to May. For the rest of the year they fed on rice straw and green fodder, if available, as supplement to concentrate mixture. Does were mated with bucks by natural mating. Bucks were selected from the flock based on body weight at 4 months and at later stage are selected for body weight at 12 month. Mating period lasted for 45 days.

\section{Statistical analysis}

Data were analyzed using the General Linear Model procedures of the Statistical Analysis System (SAS, 2004). The fixed effects considered were gender of kid, type of birth, parity of doe, season of kidding, year of kidding and interaction between (type of birth and parity of dam), (season of birth and parity of dam), (gender and parity of dam), (gender and season of birth), (gender and type of birth), (type of birth and season of birth), (gender and year of birth). The assumed model was:

$Y_{i j k l m n}=\mu+A_{i}+P_{j}+S_{k}+G_{l}+T_{m}+(T P)_{m j}+(S P)_{p j}+$ $(\mathrm{GP})_{\mathrm{lj}}+(\mathrm{GS})_{\mathrm{lk}}+(\mathrm{GT})_{\mathrm{lm}}+(\mathrm{TS})_{\mathrm{mk}}+(\mathrm{GA})_{l_{\mathrm{i}}+\mathrm{e}_{\mathrm{ijk}} \mathrm{mn},}$, Model I

$Y_{i j k l m n}$ the growth of the $n^{\text {th }}$ kids of the $i^{\text {th }}$ year of birth, $j^{\text {th }}$ parity of dam, $k^{\text {th }}$ season of birth, $I^{\text {th }}$ gender and $\mathrm{m}^{\text {th }}$ type of birth;

$\mu \quad$ is the overall mean;

$A_{i} \quad$ is the effect of $i^{\text {th }}$ year of birth, $i=1984,1985$ ... 2018;

$P_{j} \quad$ is the effect of $j^{\text {th }}$ parity of dam, $j=1,2 \ldots \geq 5$;

$S_{k} \quad$ is the effect of $k^{\text {th }}$ season of birth, $k=1$ for January, February, March, April and May, $\mathrm{k}=2$ for August, September, October, November and December, respectively;

$G_{l} \quad$ is the effect of $I^{\text {th }}$ gender, I and 2 for male and female, respectively;
$T_{m}$ the effect of $m^{\text {th }}$ type of birth, $m=1,2$ and 3 for single, twice and triplet or more;

$\mathrm{e}_{\mathrm{ijk} / \mathrm{mn}}$ random residual associated with the $\mathrm{n}^{\text {th }}$ individual assumed normally distributed with $\left(0, \sigma^{2} e\right)$.

Genetic parameters for the studied traits were also estimated. Multiple traits animal model (MTDFREML) proposed by Boldman et al (1993) was used to estimate the heritability, genetic and phenotypic parameters. The same previous fixed effects were included in this analysis in addition to the animal as random effects. The following linear model was used:

where,

$$
Y=X \beta+Z_{a}+e,
$$

$Y=$ is $N$ vector of observations of $4 \mathrm{M}, 6 \mathrm{M}$ and $12 \mathrm{M}$; $\mathrm{X}=$ is the incidence matrix for fixed effects including year of birth, parity of dam, season of birth, gender and type of birth;

$\beta=$ is the vector including the overall mean and the fixed effects;

$\mathrm{Za}=$ is the incidence matrix for random effects;

$a=$ is the vector of direct genetic effect of animal assuming.

$\mathrm{V}(\mathrm{a})=\sigma \mathrm{a}$, considering the relationship among all animals;

$\mathrm{e}=$ is a vector of random residuals normally and independently distributed with zero mean and variance $\sigma^{2} \mathrm{l}$.

The animal predicted breeding values (EBVs) were predicted from the previous analysis.

Genetic trends were obtained as the regression of the predicted breeding values on years of birth and environmental trends were obtained as the regression of year constants on years of birth.

\section{RESULTS AND DISCUSSION}

\section{Growth traits}

Least square means and standard error (SE) of different growth traits are shown in Table (2). The average of $4 \mathrm{M}, 6 \mathrm{M}$ and $12 \mathrm{M}$ months of weight were $12.14 \pm 0.02,15.49 \pm 0.02$ and $24.08 \pm 0.04 \mathrm{~kg}$, respectively. The growth traits were significant $(P<0.01)$. Mekkawy (2000) reported that the weights of Zaraibi kids are $11.64 \mathrm{~kg}$ at 4 months, $14.17 \mathrm{~kg}$ at 6 months and 22.73 at 12 month. 6M averaged $15.49 \pm .02 \mathrm{Kg}$, agreement with Aboul-naga et al (2012) and Hamed (2010) estimates. Table (2) reveal that males had significantly heavier body weights compared with females for all studied body weights, it agrees with Hamed (2010) result. 
Table 1. Analysis of variance for body weights at 120 days, $4 \mathrm{M} ; 180$ days, $6 \mathrm{M}$ and360 days, $12 \mathrm{M}$ in Zaraibi goats

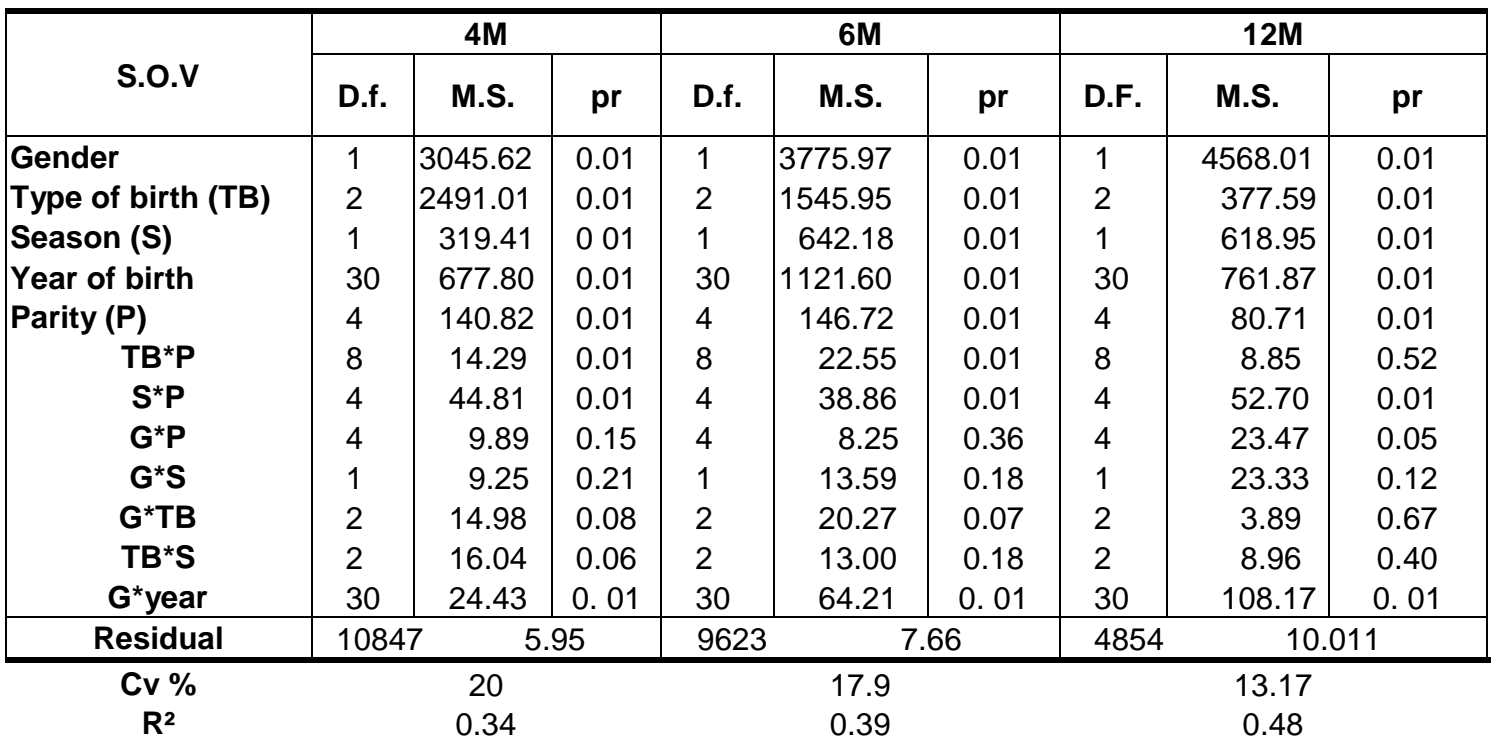

$\mathrm{CV}=$ coefficient of variation, $\mathrm{R}^{2}=$ coefficient of determination and $\mathrm{pr}=$ probability of type I error .

$(\mathrm{Pr}>.05)$ is not significant, $(\mathrm{pr} \leq .05)$ is significant, $(\mathrm{pr} \leq 0.01)$ is highly significant

Table 2. Least square means (LSM) and their standard errors (SE), for weights at4- month (4M), 6-month weight $(6 \mathrm{M})$ and 12-month weight (12M)

\begin{tabular}{|c|rc|rc|rc|}
\hline \multirow{2}{*}{ Items } & \multicolumn{2}{|c|}{$\mathbf{4 M}, \mathbf{K g}$} & \multicolumn{2}{|c|}{$\mathbf{6 M}, \mathbf{K g}$} & \multicolumn{2}{c|}{$\mathbf{1 2 M}, \mathbf{K g}$} \\
\cline { 2 - 7 } & $\mathbf{N O}$ & $\mathbf{L S M} \pm \mathbf{S E}$ & $\mathbf{N O}$ & $\mathbf{L S M} \pm \mathbf{S E}$ & $\mathbf{N O}$ & $\mathbf{L S M} \pm \mathbf{S E}$ \\
\hline Over all mean & 10937 & $12.14 \pm 0.02$ & 9713 & $15.49 \pm 0.02$ & 4944 & $24.08 \pm 0.04$ \\
Season of birth; & & & & & & \\
Season1 & 6724 & $12.64^{\mathrm{a}} \pm 0.05$ & 3861 & $15.99^{\mathrm{a}} \pm 0.06$ & 1883 & $24.40^{\mathrm{b}} \pm 0.11$ \\
Season2 & 4213 & $12.06^{\mathrm{b}} \pm 0.06$ & 5852 & $15.10^{\mathrm{a}} \pm 0.07$ & 3061 & $25.84^{\mathrm{a}} \pm 0.15$ \\
Gender; & & & & & & \\
Male & 5764 & $13.18^{\mathrm{a}} \pm 0.05$ & 4958 & $16.54^{\mathrm{a}} \pm 0.06$ & 1728 & $27.03^{\mathrm{a}} \pm 0.15$ \\
Female & 5173 & $11.52^{\mathrm{b}} \pm 0.05$ & 4755 & $14.55^{\mathrm{b}} \pm 0.06$ & 3216 & $23.21^{\mathrm{b}} \pm 0.11$ \\
Type of birth; & & & & & & \\
Single & 796 & $13.75^{\mathrm{a}} \pm 0.11$ & 677 & $16.68^{\mathrm{a}} \pm 0.13$ & 251 & $26.03^{\mathrm{b}} \pm 0.28$ \\
Twin & 6271 & $12.29^{\mathrm{b}} \pm 0.03$ & 5580 & $15.53^{\mathrm{b}} \pm 0.04$ & 2721 & $25.08^{\mathrm{ab}} \pm 0.08$ \\
$\geq$ Triplet & 3870 & $11.01^{\mathrm{c}} \pm 0.04$ & 3456 & $14.43^{\mathrm{c}} \pm 0.05$ & 1972 & $24.25^{\mathrm{a}} \pm 0.08$ \\
Parity; & & & & & & \\
$\mathbf{1}$ & 3352 & $11.77^{\mathrm{c}} \pm 0.05$ & 2932 & $14.91^{\mathrm{c}} \pm 0.07$ & 1343 & $24.44^{\mathrm{c}} \pm 0.13$ \\
$\mathbf{2}$ & 2748 & $12.38^{\mathrm{b}} \pm 0.06$ & 2430 & $15.67^{\mathrm{b}} \pm 0.08$ & 1224 & $25.47^{\mathrm{b}} \pm 0.15$ \\
$\mathbf{3}$ & 2076 & $12.37^{\mathrm{b}} \pm 0.09$ & 1893 & $15.65^{\mathrm{b}} \pm 0.11$ & 1017 & $25.28^{\mathrm{b}} \pm 0.20$ \\
$\mathbf{4}$ & 1309 & $12.62^{\mathrm{a}} \pm 0.11$ & 1172 & $15.78^{\mathrm{a}} \pm 0.14$ & 632 & $25.13^{\mathrm{a}} \pm 0.29$ \\
$\mathbf{\geq 5}$ & 1452 & $12.61^{\mathrm{a}} \pm 0.11$ & 1286 & $15.72^{\mathrm{a}} \pm 0.13$ & 728 & $25.28^{\mathrm{b}} \pm 0.25$ \\
\hline
\end{tabular}




\section{Genetic parameters}

Table (3) shows heritability estimates of studied traits. It appeared that heritability of body weights tend to increase as age increased. That is inversely matched with the environmental proportion of total variance which was found to be $0.72,0.66$ and 0.62 for $4 \mathrm{M}, 6 \mathrm{M}$ and $12 \mathrm{M}$ respectively. Heritability estimates for weight at 4,6 and 12 months of age are in Table (3). The heritability value was calculated as 0.28 for $4 \mathrm{M}$ which was lower than those reported for the same herd by Mekkawy (2000; 0.384), Comparable result $0.28 \pm 0.0028$ was obtained from a study of Rahmani at 4 months (Shaat et al 2004). The present analyses suggested that after weaning, maternal permanent environmental effects were an important source of variation. Hamed et al (2009) found that the heritability estimate for the 6 months of age was 0.12 in Zaraibi goat, which is lower than the present findings, Leo et al (2010) estimated heritability for weight at 6 month $(0.21 \pm 0.03)$, which is also lower than the present study. In contrast, Hassan et al (2013) found that the heritability for the 6 months of age was 0.45 for exotic goat which is higher than the estimate of the present study, heritability estimates for 6 month ranges (.21-.28) of ElAwady et al (2019) in the same breed. Mekkawy (2000) found that the heritability estimate for 12 mo. of age was 0.538 , which is higher than the present findings. The difference in heritability estimates could be due to the different methods used for the estimation and population sampled.

Table 3. Heritability estimates (on diagonal), environmental (above diagonal) and genetic correlations(below diagonal) for body weights at 120 days, $4 \mathrm{M}$; 180 days; $6 \mathrm{M}$ and 360 days, $12 \mathrm{M}$ in Zaraibi goats

\begin{tabular}{|c|c|c|c|}
\hline Trait & W120 & W180 & W360 \\
\hline W120 & $\mathbf{0 . 2 8}$ & 0.83 & 0.61 \\
W180 & 0.89 & $\mathbf{0 . 3 4}$ & 0.68 \\
W360 & 0.76 & 0.92 & $\mathbf{0 . 3 8}$ \\
Additive genetic & 1.81 & 3.03 & 4.79 \\
variance & & & \\
Environmental & 4.60 & 5.90 & 7.93 \\
variance & & & \\
\hline
\end{tabular}

The estimates of genetic trend (Kg/year) for investigated traits are reported in Table (4). The annual genetic changes for $4 \mathrm{M}, 6 \mathrm{M}$ and $12 \mathrm{M}$ between 1988 and 2018 generally showed an increase over time for the studied traits. The annual genetic trends were positive and significant $(p<0.01)$ for all growth traits. Estimates of annual genetic changes for $4 \mathrm{M}$, $6 \mathrm{M}$ and $12 \mathrm{M}$ were $0.091,0.121$ and 0.158 (kg/year), respectively. The annual genetic change for $4 \mathrm{M}$ $(0.091 \mathrm{~kg} /$ year $)$ in the present study was higher than those of $15.51 \mathrm{~g} /$ year reported by Latfi and Razmkabir (2019) in Markhoz goat at weaning weight (kids were weaned until $\sim 4$ months of age). The annual genetic change estimate for $6 \mathrm{M}$ in the current study $(0.121 \mathrm{~kg} /$ year $)$ was greater than those reported by Hamed (2010) in the same herd $(0.118$ $\mathrm{kg} / \mathrm{year}$ ). Also, estimate of genetic trend for $12 \mathrm{M}$ in the present study was higher than the estimates of $156 \mathrm{~g} /$ year reported by Mokhtari \& Rashidi (2010), and lower than the estimates of $448 \mathrm{~g}$ / year reported by El-Wakil and Manal Elsayed (2013) and the estimates of $1.02 \mathrm{~kg}$ per generation by Mansour et al (1977) in Barki sheep. In general, selection for growth traits were effective.

Table 4. Estimates of annual genetic changes (Kg/year) and their standard errors for kid's traits of Zaraibi goat

\begin{tabular}{|l|c|c|c|}
\hline \multicolumn{1}{|c|}{ Trait } & $4 \mathrm{M}$ & $6 \mathrm{M}$ & $12 \mathrm{M}$ \\
\hline Genetic & $0.091 \pm$ & $0.121 \pm$ & $0.158 \pm$ \\
changes & 0.007 & 0.001 & 0.001 \\
Phenotypic & $0.020 \pm$ & $0.045 \pm$ & $0.117 \pm$ \\
changes & 0.003 & 0.004 & 0.007 \\
\hline
\end{tabular}

All the estimate are significant $(p<.0 .01)$

The genetic trends among the years of birth of Zaraibi goat for 4, 6 and 12-month body weight are presented in Figs. (1, 2 and 3). Fig. (3) shows that genetic trends for WM12 trait was higher than those for other traits in this study. It agrees with Hamed (2010). Environmental trends are presented in Figs. (4, 5 and 6) for weight at 120, 180 and 360 days of age, respectively. Negative values in environmental trends indicate poor environmental care of animal the herd and absence of environmental improvement during studied period. 


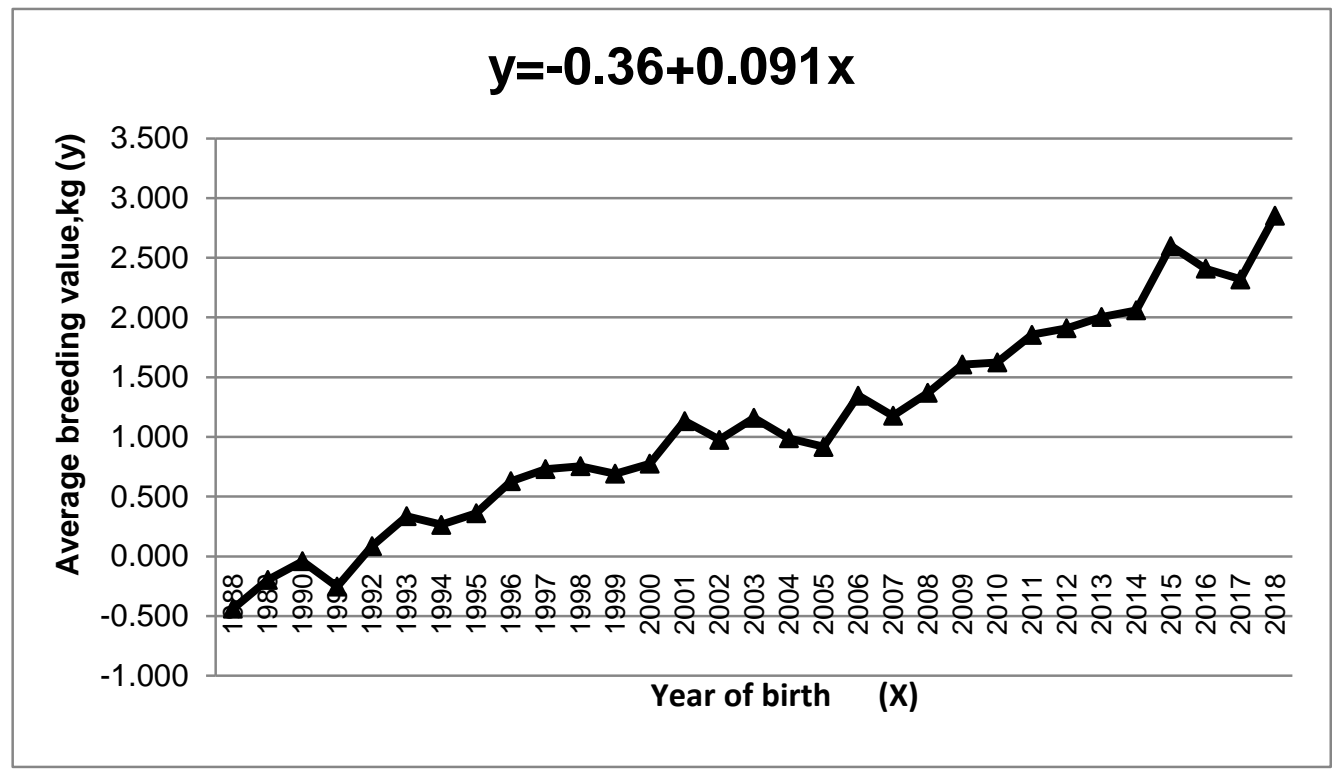

Fig. 1. Genetic trend for $4 \mathrm{M}(\mathrm{Kg})$ in Zaraibi kids

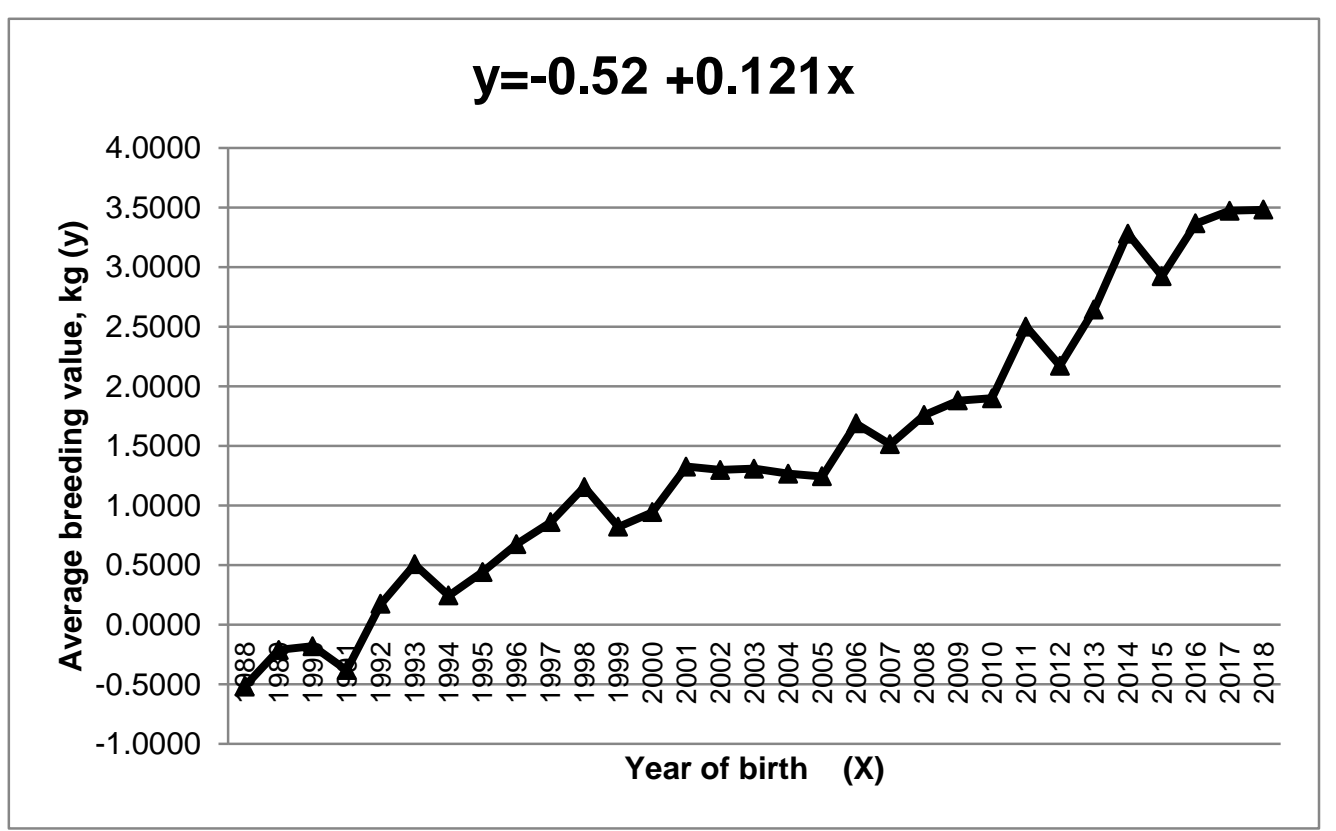

Fig. 2. Genetic trend for $6 \mathrm{M}(\mathrm{Kg})$ in Zaraibi kids 


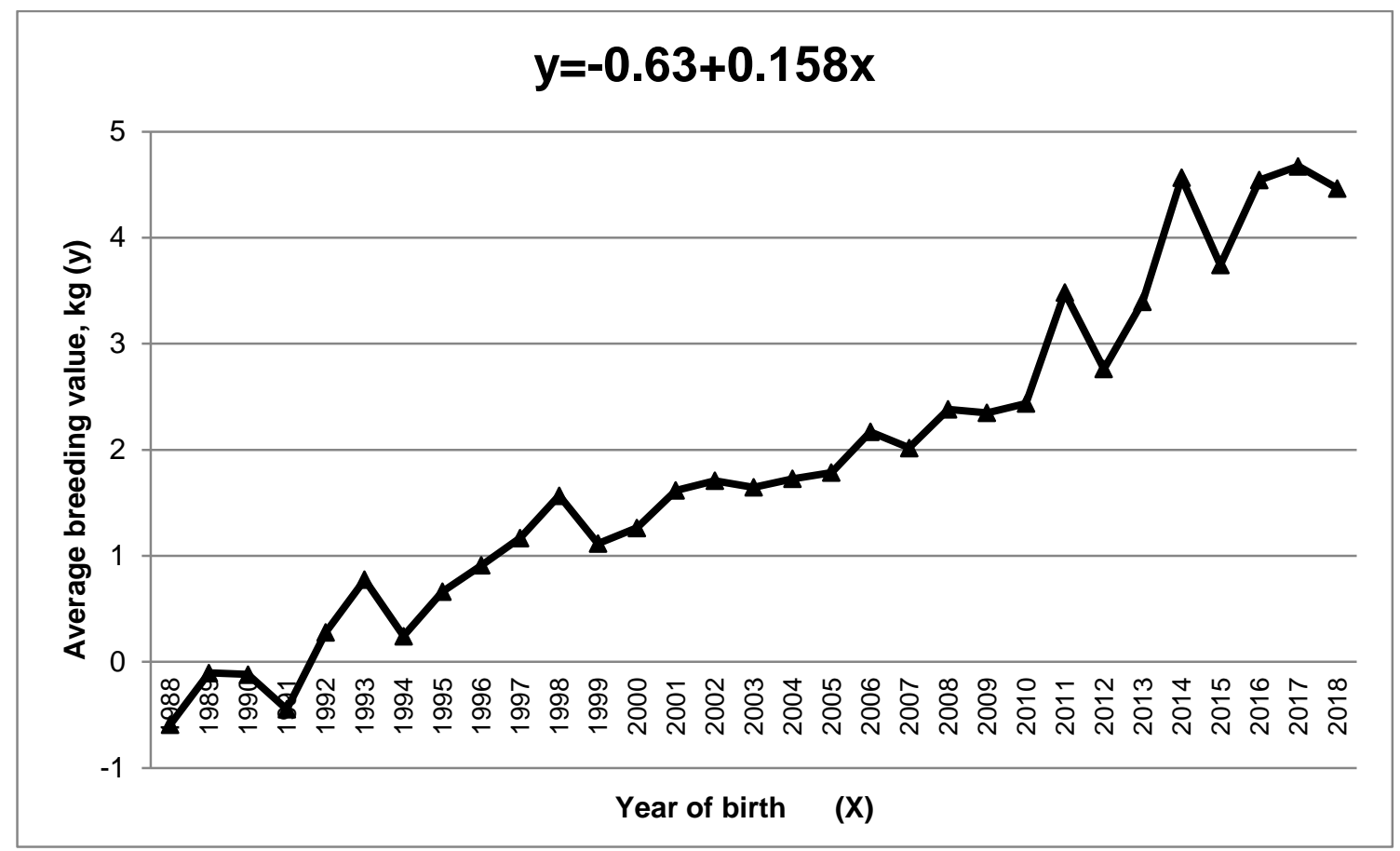

Fig. 3. Genetic trend for $12 \mathrm{M}(\mathrm{Kg})$ in Zaraibi kids

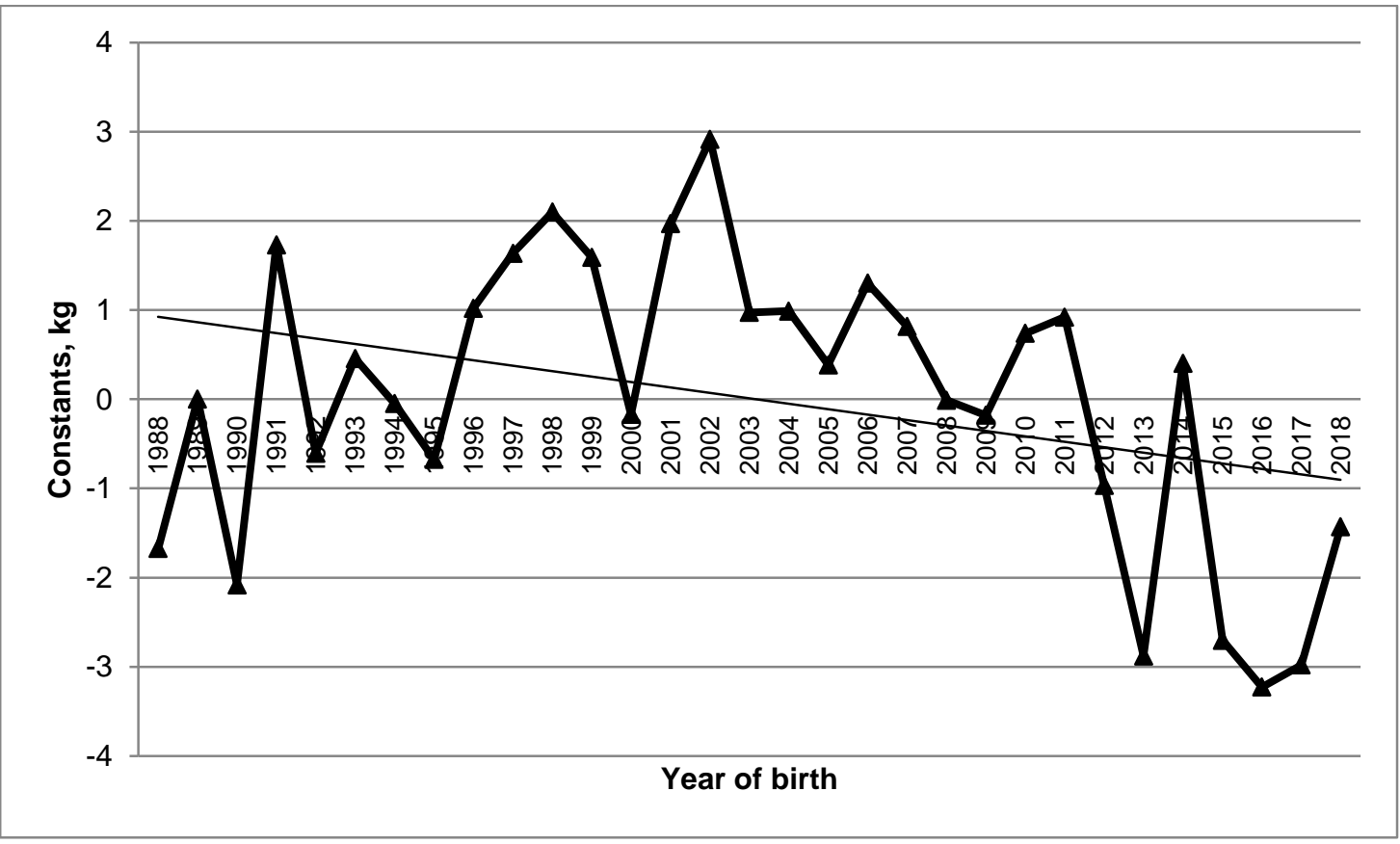

Fig. 4. Environmental trend for $4 \mathrm{M}(\mathrm{Kg})$ in Zaraibi kids 


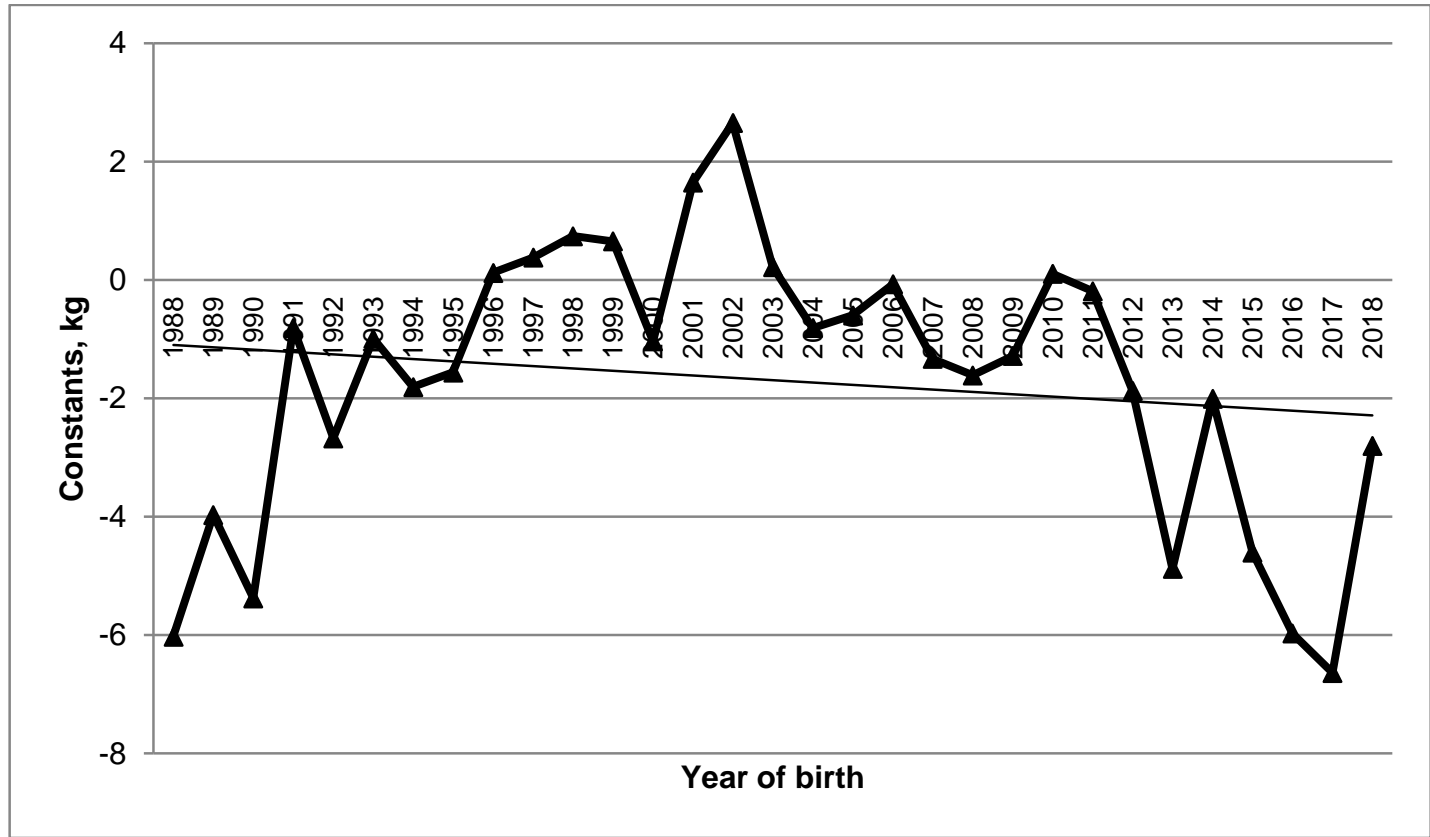

Fig. 5. Environmental trend for $6 \mathrm{M}(\mathrm{Kg})$ in Zaraibi kids

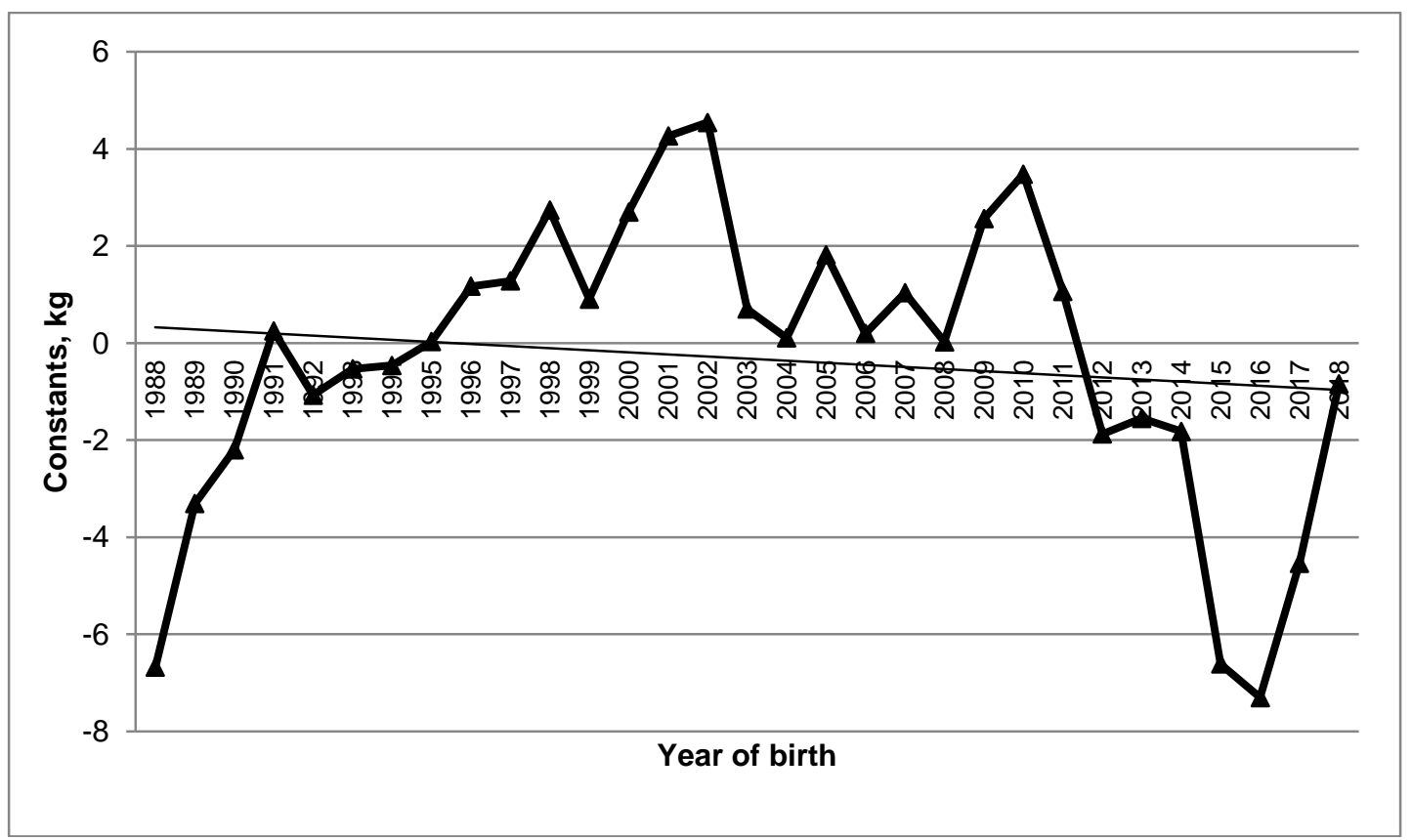

Fig. 6. Environmental trend for $12 \mathrm{M}(\mathrm{Kg})$ in Zaraibi kids 


\section{CONCLUSIONS}

Genetic trend for $12 \mathrm{M}$ trait was higher than those for other traits in this study. Negative values of environmental trend indicate poor of care for the herd during studied period. Weight at 12 months of age has the highest heritability in this study, so it is preferable to be the selection criteria to improve Body weights of Zaraibi goats. Breeders must be concerned with improving environmental conditions to benfit from the potential genetic of the animals.

\section{REFERENCES}

Abul-Naga A.M., Hamed A., Shaat I. and Mabrouk M.M.S. 2012. Genetic improvement of Egyptian Nubian goats as sub-tropical dairy prolific breed. Small Rum. Res. 102,125-130

Boldman K.G., Kriese L.A., Van Vleck L.D. and Kachman S.D. 1993. A manual for use of MTDFREML, a set of Programs to Obtain Estimates of Variances and Covariance (Draft). US. Department of Agriculture, Agriculture Research Service, 120 p.

Dhanda S.J., Taylor G.D., Murray J.P., Pegg B.R. and Sand J. 2003. Goat meat production: Present Status and Future Possibilities. Asian-Australasian J. Animal Sci., 16, 1842-1852.

El-Awady H.G., El-Moghazy M.M., Abu El-Naser I.A.M. and El-Raghi A.A. 2019. Direct and Maternal Genetic Trend Estimates for Growth Traits of Zaraibi Goats in Egypt Using Multivariate Animal Models. Int. J. of Modern Biology and Medicine, 10(1), 1-19.

Galal S., Ferial Abdel Rasoul, Anous M.R. and Shaat I. 2005. Small Ruminant Breeds in Egypt. In Iniguez, Luis. (Ed.) 2005. Characterization of Small Ruminant Breeds in West Asia and North Africa. Inter. Center for Agric. Res. In the Dry Areas (ICARDA), Alepp, Syria, 2, 146-193.

Hamed A. 2010. Genetic studies on Zaraibi goat. Ph.D. Thesis, Fac. of Agric., Al-Azhar Univ., Egypt, pp. 123-130.

Hamed A., Mabrouk M.M., Shaat I. and Bata S. 2009. Estimation of genetic parameters and some non-genetic factors for litter size at birth and weaning and milk yield traits in Zaraibi goats. Egypt. J. Sheep and Goats Sci., 4, 55-64.

Hassan M.R., Sultana S., Iqbal A. and Talukder M.A. 2013. Estimation of heritability, breeding values and genetic trends for growth traits of exotic goat. Int. J. Nat Sci., 3, 7-11.

Latifi M. and Razmkabir M. 2019. Short communication: Estimation of genetic trends for body weight traits in Markhoz goat at different ages. Span. J. Agric. Res., 17, 2171-2192.

Lee K.L., Freeman A.E. and Johnson L.P. 1985. Estimation of genetic change in registered Holstein cattle population. J. Dairy Sci. 68, 26292638.

Leo L.L.P., Gopal R.G., Chopra A. and Arora A.L. 2010. Estimates of (co) variance components and genetic parameters for growth traits of Avikalin sheep. Tropical Animal Health and Production, 42(6), 1093-1101.

Mansour H., Galal S., Hassan G.M. and Ghanem Y. 1977. Estimation of genetic trends in traits of a flock of Barki sheep. Egypt. J. Genet. Cytol. 6, 223-228.

Mekkawy W.A. 2000. Estimation of genetic parameters for growth performance of Zaraibi goats. M.Sc. Thesis, Fac. of Agric., Ain Shams Univ., Cairo, Egypt, pp. 21- 49.

Mokhtari M.S. and Rashidi A. 2010. Genetic trends estimation for body weights of Kermani sheep at different ages using multivariate animal models. Small Rumin Res. 88, 23-26.

Powell R.L., Norman H.D. and Dickinson F.N. 1977. Trends in breeding value and production. J. Dairy Sci., 60, 1316-1326.

Salwa I. El-Wakil, and Manal Elsayed 2013. Genetic, phenotypic and environmental trends towards improving body weight in BARKI sheep. Egypt. J. Sheep and Goats Sci., 8, 11-20.

SAS 2004. Statistical Analysis System. SAS Users Guide: Statistics. SAS Institute Inc. Editors, Cary, NC.

Shaat I., Galal S. and Mansour H. 2004. Genetic trends for lamb weights in flocks of Egyptian Rahmani and Ossimi sheep. Small Ruminant Research, 51(1), 23-28. 


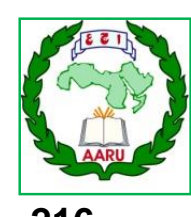

مجلة اتحاد الجامعات العربية للعلوم الزراعية، جامعة عين شمس، القاهرة، مصر

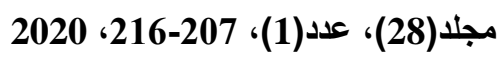

Website: http://ajs.journals.ekb.eg

التحسين الوراثي لبعض الصفات الإنتاجية في المعز الزرايبى

[14]

$$
\begin{aligned}
& \text { رشا محمد أحمد1" - منى عبدالظاهر عثمان } 1 \text { - منال السيد2 - حسين منصور2 } 2
\end{aligned}
$$

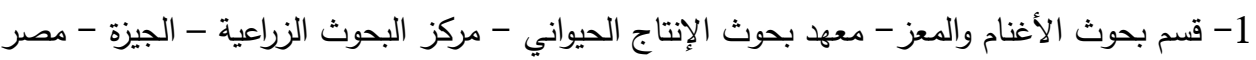

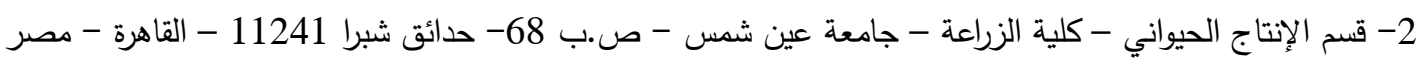

*Corresponding author: rasha m39@yahoo.com

كانت قيم الدكافئ الوراثى لصفة الوزن عند 4 شهور

.0 .28

الإتجاهات الوراثية تم تقديرها من قيمة إنحدار القيم

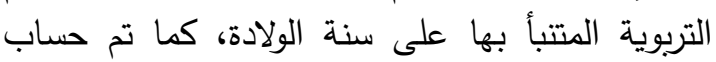

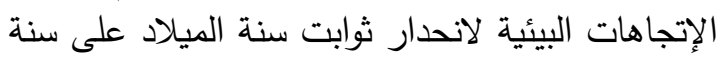

أوضحت النتائج أن اتجاهات التغيرات الوراثية كانت

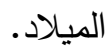

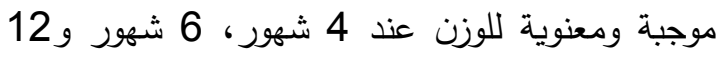

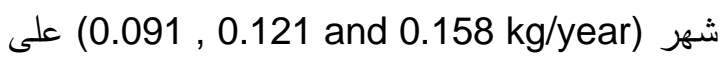
التوالي. وكانت الاتجاهات للتغيرات المظهرية كما يلى (الاتجاهات 0.045 and 0.117 kg/year) الوراثية للوزن عند 12 شهر كانت أعلى من الصفات الاتهات الأخرى فى هذه الدراسة. أوضحت الدراسة أندان أن الارتباط

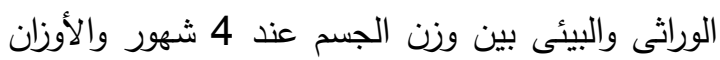
الأخرى موجباً. القيم السالبة فى الاتجاهات البئ البيئة

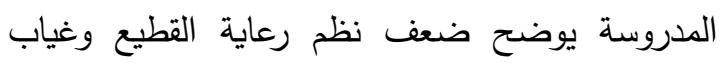

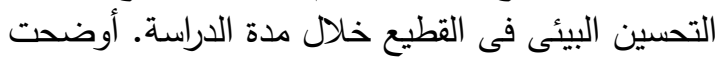

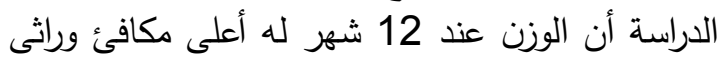

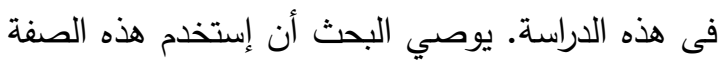

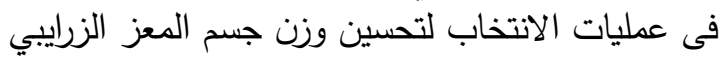

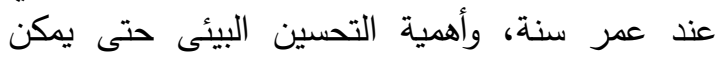
الاستفادة من الحيوانات المميزة وراثياً.

الكلمات المفتاحية: الإتجاه الوراثي، النمو، معز

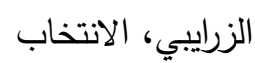

الهدف من هذه الدراسة تقييم التحسين الوراثى فى

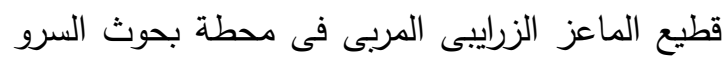
الخاصة بمعهد بحوث الإنتاج الحيوانى (APRI).

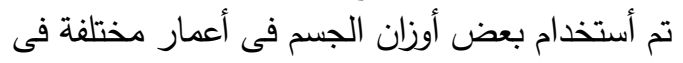
حساب الاتجاهات الوراثية والبيئية، كانت هذان التهان الأونان

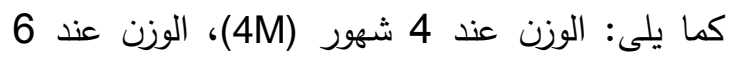

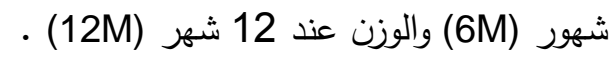
تم تجميع البيانات ومعلومات النسب من سنة 1918 واند 1988 وحتى سنة 2018، كانت تقديرات متوسطات المربعات الصغرى لأوزان الجسم كما يلى:

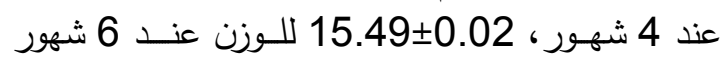
و 24.08_0.04 للوزن عند 12 شهر.

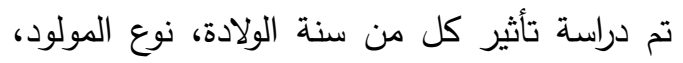

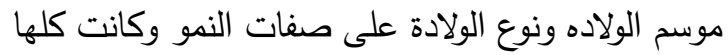

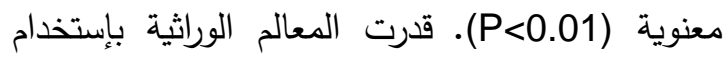

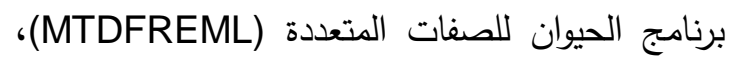
شامله العوامل الثابتة السابق ذكرها فى التحليل السابق

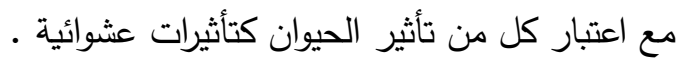

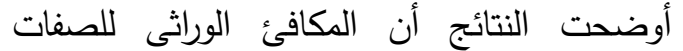

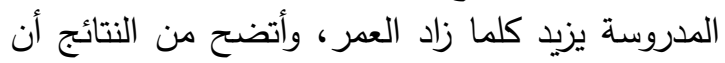

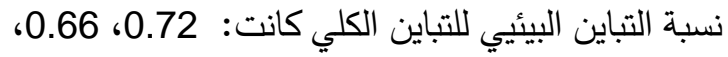

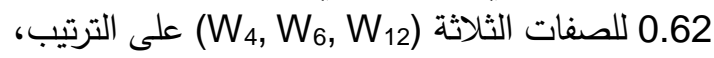


